\title{
Brutális fizika másképp - Fizikusok az igazság nyomában
}

\section{FÜLÖP Péter ${ }^{1}$}

\begin{abstract}
A különböző büncselekmények, balesetek során lejátszódó fizikai folyamatok kvalitatív és kvantitatív leírása az igazságügyi fizikus szakértő feladata. A leggyakrabban előforduló ügyek fizikai szempontból jól csoportosithatók. A hajítások és a deformációk fizikáján keresztül az olvasó átfogó képet kaphat a gyakorlatban alkalmazott módszerekről. A tanulmányban kitérek néhány fogalom, mennyiség rövid magyarázatára is, amelyek a jelenségek megértését segítik.
\end{abstract}

Kulcsszavak: törvényszéki fizika, idegenkezüség, öngyilkosság, baleset, gyermekbántalmazás, Newton-törvények, erő, impulzus, mozgási energia, hajítások, deformációk

\section{Bevezetés}

„A fizika szórakoztató, de nem vicc!””

A Nemzeti Szakértői és Kutató Központ (NSZKK) Fizikai és Szervetlen Analitikai Osztályán tevékenykednek az igazságügyi fizikus szakértők. A különböző anyagok (például festékek, fémek, üvegek) fizikai és kémiai tulajdonságaik alapján történő összehasonlító vizsgálata mellett egyre növekvő számú esetben igyekeznek a szakértôk eleget tenni a hatósági kirendeléseknek a fizika klasszikus területeinek kriminalisztikai szemléletû alkalmazásával. A fizikusok feladata - döntően a büntetőeljárások során - valamilyen esemény vagy cselekmény (például baleset, bántalmazás) során lejátszódó fizikai folyamat rekonstruálása, a kirendelő határozatban vagy végzésben ezzel összefüggésben feltett kérdések megválaszolása.

A Pedig jó ötletnek tûnt vagy az Állítólag címủ tudományt népszerüsítő, ismeretterjesztő műsorokban kétségkívül szórakoztató, de fájdalmas (gyakran komoly személyi sérüléssel járó) mutatványok, balesetek, illetve különböző mendemondák, filmes trükkök mögött rejlő fizikai jelenségek, törvényszerűségek bemutatására, magyarázatára kerül sor. Ezekben a sorozatokban egy adott állítást, történetet természettudományos módszerekkel megvizsgálják, amit aztán az elvégzett kísérletek alátámasztanak vagy megcáfolnak, esetleg részben lehetségesnek nyilvánítanak. Amennyiben az állítás

\footnotetext{
FÜLÖP Péter, igazságügyi szakértőjelölt, Nemzeti Szakértői és Kutató Központ Péter FÜLÖP, candidate for forensic expert, Hungarian Institute for Forensic Sciences https://orcid.org/0000-0001-7792-5026, fulopp@nszkk.gov.hu

2 Härtlein Károly, BME Fizikai Intézet, mesteroktató
} 
maga a sértett, a tanú vagy a gyanúsított vallomása, a történet a búncselekmény, akkor az igazságügyi fizikus szakértők nagyon hasonló módszerekkel segítenek kideríteni a bűnüldöző szerveknek, hogy valójában mi is történhetett. Innen ered jelen tanulmány címe is, amely egyrészt az említett műsorokhoz hasonló tematikájú, Brutális fizika címú magyar ismeretterjesztő sorozatra utal, másrészt vonatkozik a továbbiakban közölt esetekre.

\section{Módszerek}

A fizika a természeti jelenségek leírásával és a közöttük lévő kapcsolatok, törvényszerűségek feltárásával foglalkozó tudomány. Ez a tudományág az ismereteket részben a kísérletekből, részben az elméleti megfontolásokból meríti. Ennek megfelelően megkülönböztetnek két fő irányt, a kísérleti és az elméleti fizikát. ${ }^{3}$ Másképpen az induktív ismeretszerzést választva tapasztalati úton, míg a deduktív stratégiával absztrakciókon keresztül jutunk el a megoldáshoz. ${ }^{4}$

Az igazságügyi fizikus szakértők a természettudományos módszertant alkalmazzák a fizikai megismeréshez. A gyakorlatban ez annyit tesz, hogy a fizikus szakértők a hatóság által rendelkezésre bocsátott ügyiratok adatai alapján eldöntik, hogy helyszíni szemlét tartsanak-e, illetve zavaró hatásoktól mentes kísérletet tervezzenek és hajtsanak végre. A feladatok elvégzése után íróasztal mellett egy modellalkotási és számolási folyamat következik. Ha az analitikus gondolkodás nem viszi előbbre az ügyet, akkor sokszor az intuíció segíthet. Ebben az esetben a fizikusok megérzéssel jönnek rá a megoldásra, amit a természettudományos szemléletnek megfelelően természetesen bizonyítani szükséges. A szakértők ezeket a módszereket nem külön-külön alkalmazzák, hanem azok szoros kölcsönhatásban vannak egymással.

\section{Kirendelői kérdések}

Hogyan állíthatók párhuzamba a kirendelői kérdések a természettudományos, fizikai megismerés folyamatával?

A klasszikus vagy newtoni mechanika a testek mozgásának leírásával ${ }^{5}$ és a mozgások okait feltáró törvényekkel ${ }^{6}$ foglalkozik. A mozgástan arra a kérdésre keresi a választ, hogy hogyan mozognak a testek, míg az erőtan arra ad választ, hogy miért éppen úgy mozognak. ${ }^{7}$ Alapvetően a kirendelő hatóság egy természettudós kíváncsiságával fogalmazza meg kérdéseit: „Hogyan?” és „Miért?” kérdésekre keresi a válaszokat.

A hétköznapi élet szerteágazó területein bekövetkezhetnek tragikus események, amelyek során a résztvevők büntetőjogi felelőssége is felmerülhet. Amennyiben a nyo-

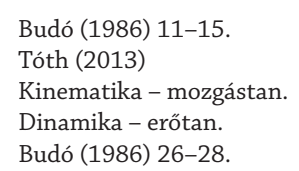


mozó hatóság által lefolytatott eljárás részeként a bizonyítandó tény megállapításához vagy megítéléséhez különleges szakértelemre van szükség, akkor - az új Be. 188. § (1) alapján ${ }^{8}$ - szakértőt kell alkalmazni. Ilyen bizonyítandó tény lehet a vizsgálandó esemény, egy baleset (például munkahelyi és sportbalesetek) vagy egy erőszakos cselekmény (például öngyilkosság, bántalmazás stb.), amelyek helyszínén hátrahagyott bizonyítékok alapján az ügy szempontjából releváns mozgássorozatot, erőhatásokat, testtartást vagy testhelyzetet kell rekonstruálni. A történtekkel kapcsolatban a sértett, a gyanúsított és a tanúk vallomása is ellentmondásos lehet. A szakértőknek ilyenkor a történetek valóságtartalmának vizsgálata az elsődleges célja. Annak eldöntése a gyakorlott fizikus számára is nehéz feladat, hogy fizikailag megtörténhetett-e egy esemény úgy, ahogy elmondják, vagy sem. Minden esetben célszerű a valóságos testek olyan tulajdonságait elhanyagolni, amelyek a vizsgált jelenség szempontjából lényegtelenek. Az idealizált testek (például tömegpont, merev testek, rugalmas szilárd testek) viselkedése egyszerübben leírható. A szakértő az így kapott modell segítségévél, a mechanika mozgásegyenleteinek és a Newton-törvények alkalmazásával, valamint a mozgás kinematikai jellemzőinek ismeretében a szakértői véleményben megfogalmazza, valószínúleg mi történhetett az ütközés, esés, ütés stb. során. A véleményben gyakran ki kell térni arra, hogy mekkora erővel dobhatták el a tárgyat, mekkora lehetett a becsapódás energiája vagy egy szúrás ereje, az milyen sérülést okozott, okozhatott volna stb. A magyarázatok elengedhetetlen része a bizonyítékokból és az eredményekből levonható kriminalisztikai következtetés is, mint például annak eldöntése, hogy az emberi test idegen- vagy önkezű cselekmény, esetleg véletlenszerű baleset következtében került-e a feltalálási helyére? Előfordulhat azonban az is, hogy a rendelkezésre álló információk és eredmények nem elégségesek ahhoz, hogy fizikailag különbséget lehessen tenni az eltéró esetek között.

\section{A forenzikus fizika és határterületei}

A 20. század második felétől megfigyelhető egy folyamat, amely során a tudományok közti határok elmosódnak, ezek mentén inter- és multidiszciplináris szakterületek alakulnak ki. A forenzikus fizika sem kivétel ez alól, hiszen a balesetek, az erőszakos cselekmények gyakran személyi sérüléssel, dologi kárral járnak, és így a bizonyítandó tény megítéléséhez a sérüléssel összefüggő erőhatások nagyságának megállapítása is szükségessé válhat. A sérülést létrehozó erőhatás (például eszköz, tárgy és az emberi test közötti kölcsönhatás) nagyságának és az egészségügyi kockázatának (veszélyességi fokának) megállapítása nem egyszerű feladat. A sérült testrész anatómiai sajátossága, az okozó tárgy mérete, alakja, maga az erőhatás nagysága és iránya befolyásolja a külső hatásra bekövetkező mechanikai sérülés típusát, valamint jellegzetességeit. Ezek a sebek, törések hordozhatnak olyan sajátosságokat, amelyek az elkövetés eszközére vagy a kölcsönhatás jellegére utalhatnak. Ilyen esetekben a fizikus szakértő mellett az igaz-

2017. évi XC. törvény a büntetőeljárásról. 
ságügyi orvos és nyomszakértő bevonásával, egyesített szakértői vélemény keretében lehetőség nyílik az ok-okozati összefüggések komplexebb elemzésére. Megállapításokat lehet tenni, hogy az emberi testen lévő sérülések tompa erőbehatás vagy éles, hegyes tárgy hatásaként jöttek-e létre. Azonban a szakértők számára nemcsak a meglévő sérülések, hanem azok hiánya is hordozhat kriminalisztikai információt.

Az olvasó számára a szakértői munka során legtöbbször előforduló, fizikai szempontból tematikus csoportokba sorolható, érdekesebb eseteket gyüjtöttem össze a teljesség igénye nélkül.

\section{A hajítások szerepe a fizikus szakértői gyakorlatban}

A mindennapi életben (elég, ha csak a labdajátékokra gondolunk) az egyik leggyakrabban előforduló mozgástípus a hajítás. A hajítás kezdősebességének iránya szerint a függőleges, a vízszintes és a ferde hajításra vegyünk néhány példát a kriminalisztikai gyakorlatból!

\section{Felfelé hajítás: képes lehet-e egy konzervdoboz súlyos sérüléseket okozni?}

Az emberek egy része tart háziállatot otthonában. A kedvencek gondozása, etetése költséges, ezért sokan a nagy kiszerelésű, gazdaságos konzerveket részesítik előnyben. A háztartásainkban sokféle hétköznapi eszköz, tárgy foglal helyet a szekrényekben, a polcokon, és nem is gondolnánk, hogy ezek hő (például egy lakástűz) hatására gyilkos fegyverré válhatnak. Az emberölés elkövetői gyakran balesetnek, öngyilkosságnak akarják beállítani tettüket. A nyomozást meg tudja nehezíteni, ha a tárgyi bizonyítékokat megpróbálják eltüntetni. A megsemmisítés egyik módja lehet a bűncselekmény helyszínének felgyújtása. Ha egy lakóingatlan kiégett helyiségében holttestre bukkannak, kézenfekvő lehet először balesetként tekinteni a halálesetre, azonban lehetnek a helyszínen olyan tényezők, amelyek az idegenkezűséget sem zárják ki. A kérdést mindenképpen igazságügyi szakértők segítségével lehet körbejárni. A tűzvizsgáló a tűz keletkezésének mechanizmusát, helyét feltárja, az orvos szakértő nyilatkozik a holttesten található sérülésekről, a halál okáról és ezek közötti ok-okozati összefüggésekről. Egy emberi testen lévő külső, illetve belső sérülés általában külső erő hatására bekövetkező fizikai elváltozásként értelmezhető. A nyomozás során felmerülő eseménysorozat, egy feltételezett mozgásmechanizmus felderítése pedig a fizikus szakértő kompetenciakörébe esik.

Vajon a hő hatására felrobbanó konzervek hogyan mozognak, okozhatnak-e jellegzetes sérüléseket?

Ennek eldöntésére a kereskedelmi forgalomban kapható, például 11 űrtartalmú és 1,24 kg tömegú konzerveket szabadtéri körülmények között, különböző elrendezésben, PB-gázpalackkal kb. $400{ }^{\circ} \mathrm{C}$-ra felhevítjük. A melegítés hatására a konzervdoboz tartalma forrni kezd, a képződő gőz nyomása által a doboz tetejére ható erő rövid idő alatt meghaladja a konzervdoboz mechanikai szilárdságát és egy háromfokozatú ra- 
kétaként fog viselkedni. A lendületmegmaradás tételének értelmében a konzervrakéta üzemanyagaként szolgál a doboz leváló fedele, a hirtelen (adiabatikusan) kitáguló gáz, végül a konzerv szilárd tartalma, melyek három lépésben gyorsítják közel függóleges irányban a konzervet.

A rakéta pusztító erejét (a mozgási energiáját és a sebességét) egy egyszerű modellkísérleten keresztül meg lehet becsülni. A konzervek mozgásáról videofelvételeket készítünk. A felvételeket egy erre a célra alkalmas szoftver ${ }^{9}$ segítségével elemezzük. A kamerafelvételek számítógépes elemzése általában úgy történik, hogy a programban először egy digitális mérőszalagot kalibrálunk. Ehhez célszerű a mozgás síkjában egy olyan tárgyat választani, aminek pontosan ismerjük a méretét. Ezt követően egy derékszögű koordináta-rendszert, úgynevezett vonatkoztatási rendszert rögzítünk a mozgás kezdőpontjához, majd a vizsgált test tömegközéppontját bejelöljük, és képkockáról képkockára követjük a mozgását. A program grafikusan megjeleníti a tömegközéppont helyének koordinátáit (ahol az x a vízszintes, az y a függőleges helyzet) az idő függvényében. A mozgás út-idő grafikonjából a tárgy sebességére, gyorsulására lehet következtetni (1. ábra).

Amennyiben az emberi koponyacsont (például homlokcsont) átlagos vastagságát 5 mm-nek vesszük, annak töréséhez mintegy 4-5000 N erőhatás szükséges. Bármilyen fizikai objektumnak a mozgásállapotából fakadóan mozgási energiája van. A mozgási energia a kérdéses fizikai objektum tömegétől és sebességétől függ. ${ }^{10}$ Amennyiben az 1,24 kg tömegű konzerv $20 \mathrm{~km} / \mathrm{h}$ sebességgel mozog, $20 \mathrm{~J}$ mozgási energiát képes „tárolni”. A koponyacsontok, lágy szövetek elnyelik ezt a mechanikai energiát, így az ütközés agy- és arckoponya-sérüléseket, valamint az ezzel járó agyzúzódást idézhet elő. A videó adataiból meghatároztam, hogy a konzervdobozok felrobbanásuk után közvetlenül mintegy 200 km/h, függőleges irányú sebességgel mozogtak (felfelé hajítás), és $2000 \mathrm{~J}$ mozgási energiával bírtak.

\footnotetext{
https://physlets.org/tracker/ (2019. 10. 01.)

$10 \quad E_{\text {mozg }}=\frac{1}{2} m \cdot v^{2}$, ahol $m$ a test tömege, $v$ a test sebessége.
} 


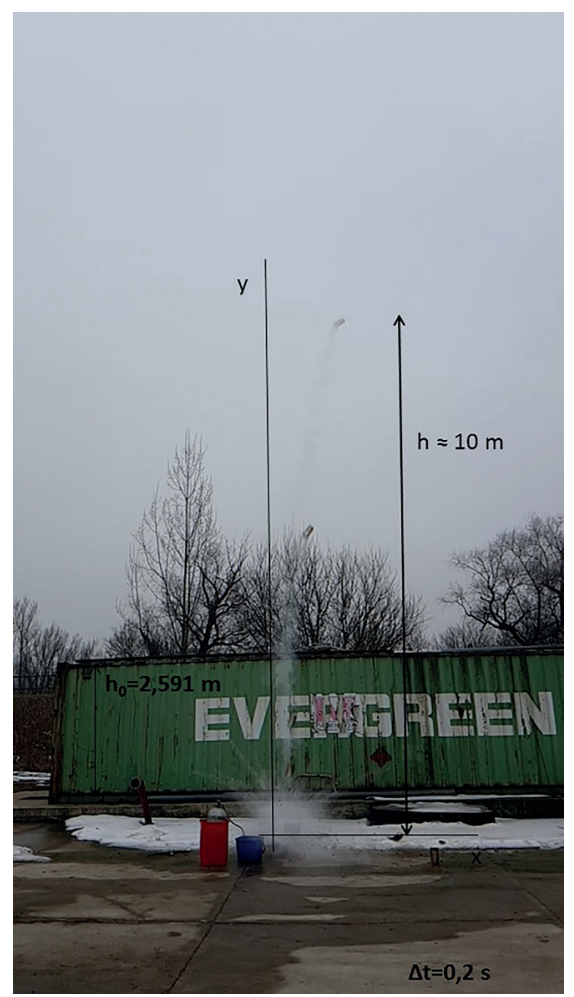

1. ábra: A konzervdoboz mozgása. Forrás: a szerző szerkesztése

\section{Vízszintes hajítás: egy vízbe lökés fizikája}

A vízszintes hajítás két független mozgás eredője, amelynek vízszintes irányú komponense egy egyenes vonalú egyenletes mozgás, függőleges irányú komponense pedig egy szabadesés. A vízszintes irányú kezdősebességgel elhajított test ennek eredményeképp ideális esetben egy parabolapályán mozog. Amennyiben egy térfigyelő kamera felvételén csak részben azonosítható az eseménysorozat (például csak a vízszintes irányú lökés látható, a zuhanás már nem), akkor a mozgás kezdősebességének becslése alapján a hajítás során vízszintes irányban a kiindulási helytôl megtett út, az eltávolodás mértéke kiszámítható. Ha valakit vita közben egy folyó ismert magasságú partjáról a vízbe löknek, az aktuális vízállás és az eltávolodás számadataiból a vízbe esés helyére, a sérülésekből annak módjára lehet következtetni.

A sikeres vizsgálat feltétele, hogy kalibráljuk a digitális mérőszalagot, majd a vizsgált személy súlypontját (felnőtt esetében a köldök magassága) bejelöljük. A súlypont mozgását követve a program grafikusan megjeleníti a kiválasztott tömegpont helyének koordinátáit (ahol az x a vízszintes, az y a függőleges helyzet) az idő függvényében (2. ábra). 


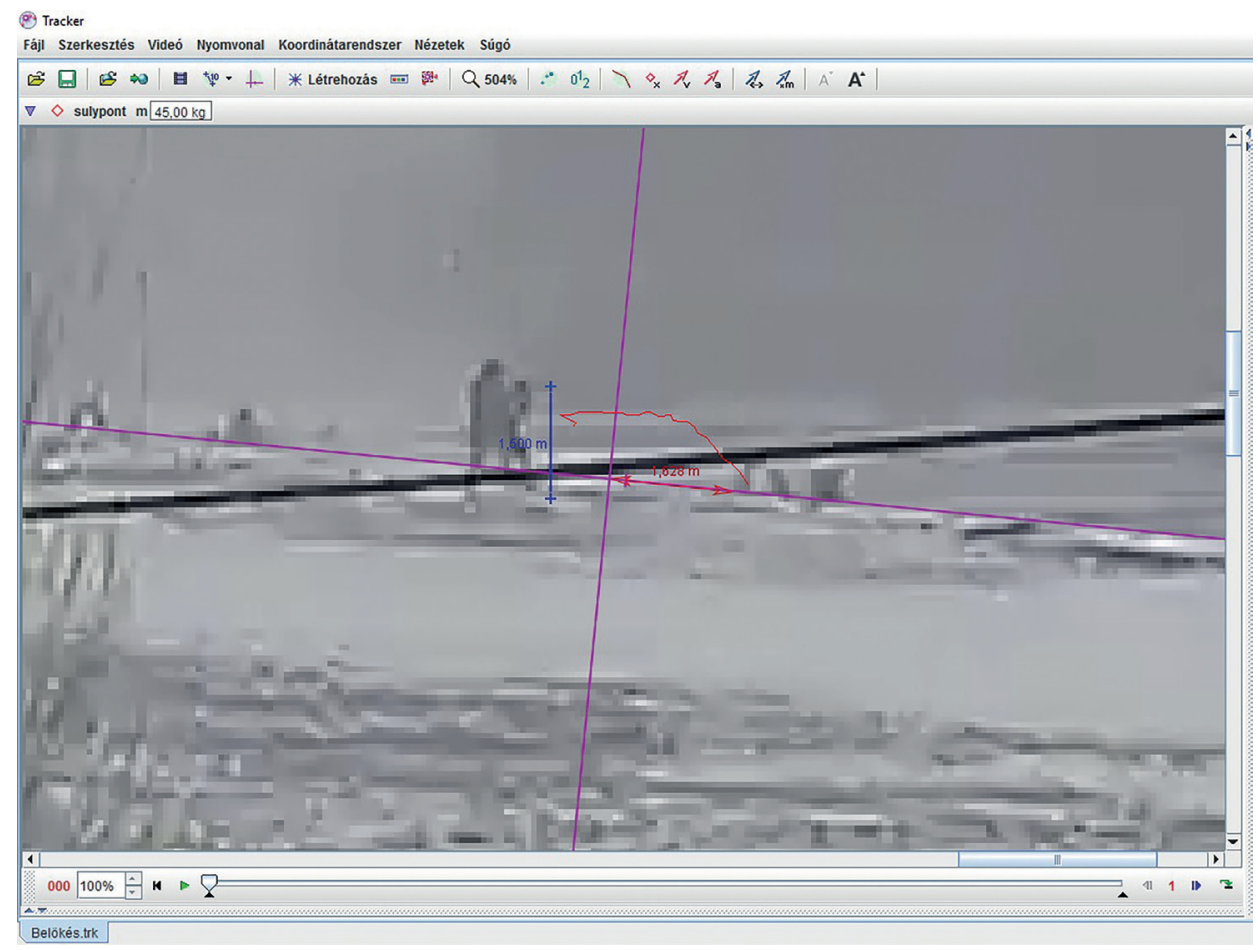

2. ábra: A súlypont pályája a Tracker videóelemző és modellező programban. Forrás: a szerző szerkesztése

A vízszintes hajítások esetében az út-idő grafikon képe egy egyenes, ami azt jelenti, hogy a két mennyiség között egyenes arányosság áll fenn, hányadosuk állandó, amely a test mozgására jellemző mennyiséget adja meg (3. ábra). A grafikonon látható egyenes tehát fizikai jelentést hordoz, a meredekségéből a test sebessége (v) kiolvasható. 


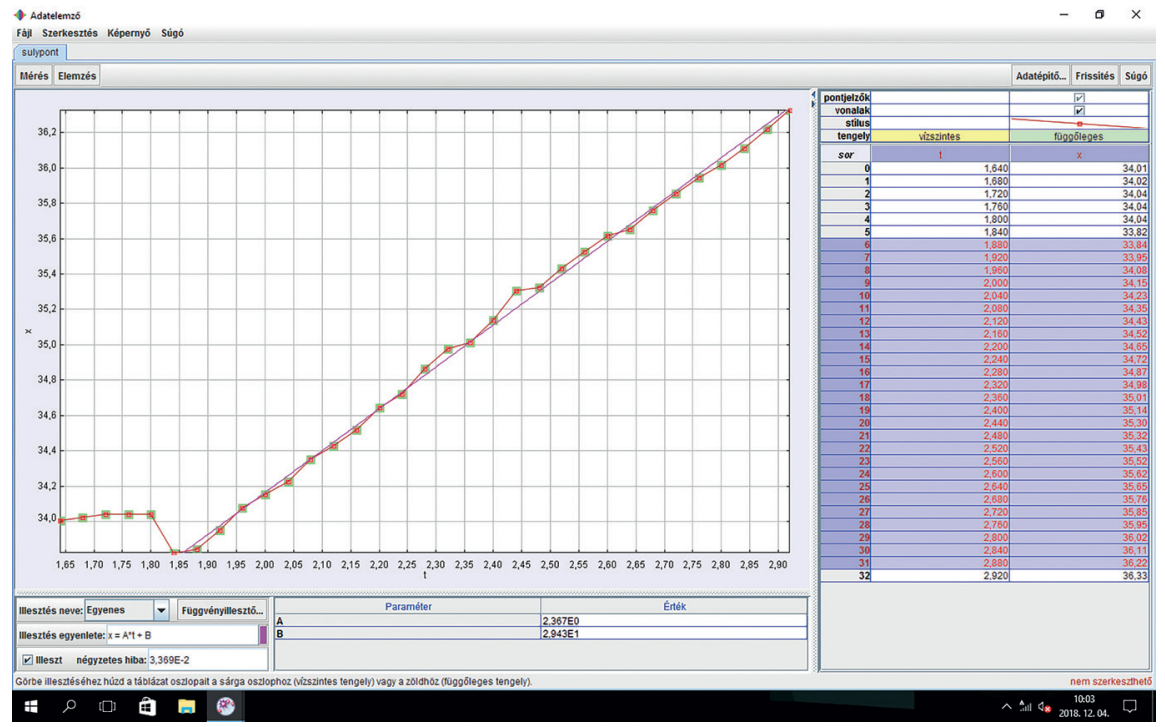

3. ábra: A súlypont mozgásának hely-idő grafikonja a Tracker programban.png. Forrás: a szerző szerkesztése

A példaként szolgáló esetben az emberi test, egy erőteljes lökéssel kb. 2,3-2,4 m/s sebességre volt felgyorsítható, és a néhány tizedmásodpercnyi zuhanást követően, a kérdéses kb. 4,3 m magasságú parttól kb. 2 m-re eltávolodva eshetett a folyóba.

\section{Ferde hajítás: az elhajított tárgyak ütközésének fizikai jellemzôi}

Az ütközések rugalmasságát egy dimenzió nélküli arányszámmal, az úgynevezett $\varepsilon$ ütközési együtthatóval jellemezhetjük. Gyakorlatilag az ütközés elótti és utáni impulzusok $^{11}$ hányadosa adja meg az $\varepsilon$ értékét, ami egy 0 és 1 közé eső szám. A két szélsőértéknek fizikai jelentése van; $a z \varepsilon=0$ esetén tökéletesen rugalmatlan, illetve $a z \varepsilon=1$ esetén tökéletesen rugalmas ütközésről beszélhetünk. A tökéletesen rugalmas ütközés egy idealizált eset, a valóságban mindig van mechanikai energiaveszteség, pontosabban a mozgási energia alakváltozással kapcsolatos munkává, tökéletesen rugalmatlan ütközéskor hőenergiává alakul át. ${ }^{12}$

A gyakorlatban sokszor kapunk olyan feladatot, ahol a sértett, a tanú vagy a gyanúsított másképp emlékszik a történtekre. Ilyenkor az előadottak valóságtartalmát ellenőrizni szükséges, és az események közül a fizikailag lehetséges vagy legvalószínúbb cselekménysorozatot kell megadni.

\footnotetext{
$p=m \cdot v$, ahol $m$ a test tömege, $v$ a test sebessége.

Budó (1986) 207-221.
} 
Képzeljünk el egy elmérgesedett családi vitát! Az egyik fél dühében egy viszonylag nehéz, 1 kg tömegű váza segítségével győzködi vitapartnerét, aki ettől súlyos arckoponya-sérülést szenved. A vita résztvevői két, egymástól kismértékben eltérő magyarázatot adnak a történtekre. A gyanúsított azzal védekezik, hogy a vázát az előszobában álló szekrénynek akarta hajítani. Az eldobott tárgy a szekrényen irányt változtatva a hozzá közel álló sértett fejét találta el. Ezzel szemben a sértett azt állítja, hogy a hajítás pillanatában a szekrény közvetlen közelében tartózkodott, amikor a gyanúsított kb. 4 m távolságból szándékosan fejbe dobta a vázával. A két történetet kísérletekkel lehet bizonyítani, illetve cáfolni. Ilyen esetekben arra törekszünk a nyomozó hatósággal együttműködve, hogy lehetőség szerint az eredeti bűnjel felhasználásával tudjunk modellkísérleteket végezni. Amennyiben a vizsgálat - a modellkísérletek során - feltehetően a bűnjel megsemmisülésével, sérülésével jár, minden esetben kötelező a kirendelő hatóságot tájékoztatni, és engedélyt kell kérni a kísérlet végrehajtásához. Az engedély birtokában a lehetséges történeteknek megfelelően megtervezzük az adott kísérletsorozatot. Például a fenti esetben különböző távolságokból (1 és $4 \mathrm{~m}$ ) egy bútorlapnak hajítjuk a vázát. A váza mozgásáról videófelvételek készülnek, amiket a már leírt módon, számítógépes szoftverrel feldolgozunk (4. ábra).

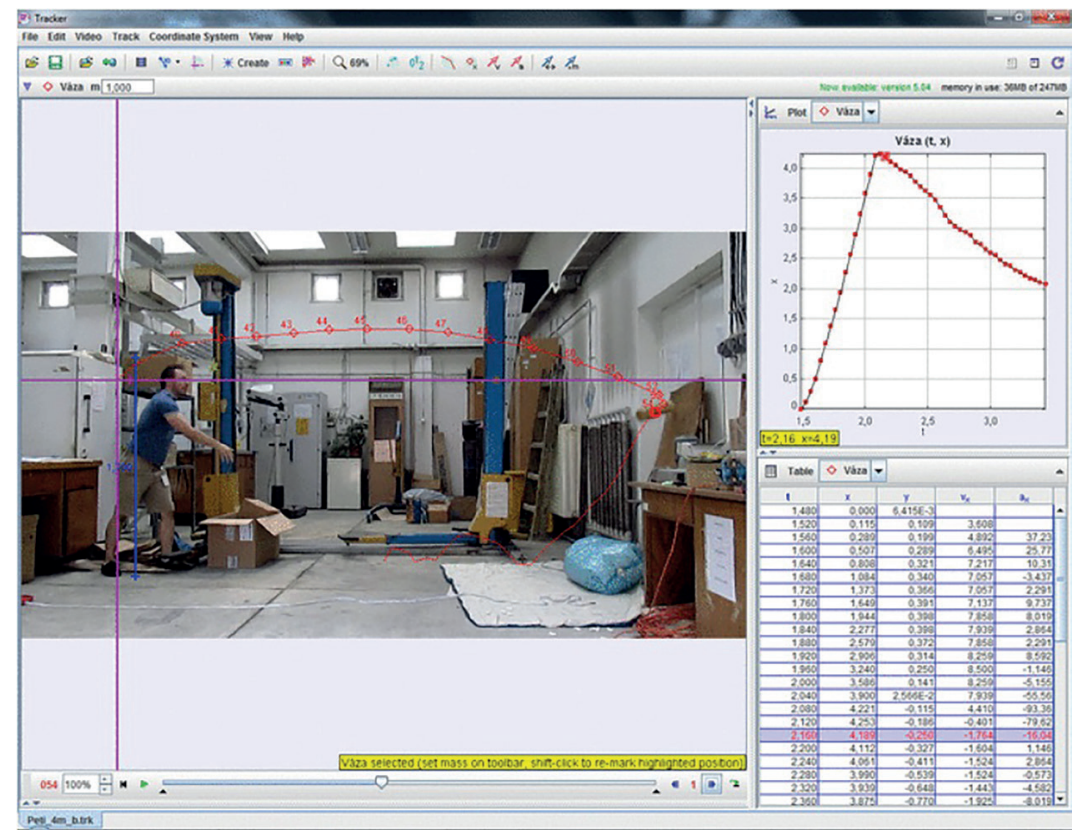

4. ábra: A váza hajításának vizsgálata a Tracker videóelemző és modellező szoftverben.

Forrás: a szerző szerkesztése

A videófelvételek elemzése során arra jutottam, hogy a váza mozgási energiája a bútorlapnak történő ütközés után legalább 88\%-ban elvész, belső energiává alakul. A hom- 
lokcsont töréséhez kb. 20-25 J mozgási energia szükséges. Ekkora mozgási energiát akkor „tárol” az 1 kg tömegú, mozgó váza, ha a fejnek ütközéskor legalább 25 km/h sebességgel rendelkezik. Innen könnyen belátható, hogy a gyanúsított által előadott eseménysorozat elég valószínútlen, hiszen a kísérletek szerint saját erejével mintegy $208 \mathrm{~km} / \mathrm{h}$ sebességre kellett volna a vázát felgyorsítania ahhoz, hogy a bútorlapon történő megpattanáskor fellépő energiaveszteség után is legyen elég energiája a kérdéses sérülés létrehozására. (Emlékezzünk vissza, hogy hasonló sebességértéket kaptunk, amikor a felrobbanó konzerv rakétaként viselkedett!) Számítások szerint a kérdéses váza egy felnőtt izomerejének köszönhetően az eldobás pillanatában 14-38 J mozgási energiával rendelkezhet.

\section{A ferde hajítás speciális esete: a magasból történö kizuhanás}

Amennyiben holttestet találnak egy épület, egy meredek sziklafal alatt, tanúk hiányában a nyomozó hatóság részéről több kérdés is felmerülhet. A ferde hajítás mozgásegyenletéből kiindulva az állva és az ülve kidőlő emberi test (merevtest-modell) súlypontjának földet érés utáni helyét (az esés függőleges vetületétől való távolságát) meg lehet becsülni. Ilyen esetekben a fizikus szakértő az ügyiratok áttekintését követően helyszíni szemlét tart, amelynek során a bűnügyi technikus által rögzített fényképek felhasználásával a lezuhant test helyzetét (súlypont eltávolodása, deviációja) távolságméréssel meghatározza, majd a tényleges feltalálási helyzet és a számolt, elméleti feltalálási hely viszonyát megvizsgálja. Ez alapján rekonstruálható egy eseménysorozat, amiből kriminalisztikai következtetés vonható le: az emberi test idegen- vagy önkezű cselekmény, esetleg véletlenszerú baleset következtében került-e oda, ahol a testet megtalálták. A gyakorlatban azonban sokszor nem egyértelmű ennek eldöntése, ugyanis fizikai értelemben csak a balesetszerűséget tudják megerősíteni vagy kizárni.

Történt, hogy egy fiatal nő holttestére bukkantak egy kirándulók körében népszerü helyen. A holttestet a személyes tárgyaitól viszonylag messze, nem a magas helyről kiesésre jellemző testhelyzetben fedezték fel. A helyszíni terepviszonyok nemcsak a geometriai méréseket nehezítették, hanem a súlypont mozgásának korábban említett rekonstruálását is. A számítások során megállapítható volt, hogy a feltételezett kizuhanási hely és a megtalálási hely közötti vízszintes távolság a véletlen, balesetszerü leesést valószínűsíti vagy szándékos cselekmény következménye. Ha a baleset kizárható, akkor azt kell vizsgálni, hogy a kizuhanás helyének jellegzetességei (a korlát geometriája, a tereptárgyak, a növényzet) alapján a nekifutásból, öngyilkossági szándékból történő leugrás, vagy az idegenkezűség (emberölés) látszik-e lehetségesnek. A nyomozást ráadásul az sem könnyítette meg, hogy a sérülések keletkezési mechanizmusát - sem fizikus, sem orvos szakértői módszerekkel - egyértelműen nem lehetett megállapítani, mivel tompa tárggyal történő ütés és tompa felülethez történő ütődés között nehezen tehető különbség. 


\section{A deformációk szerepe a fizikus szakértői gyakorlatban}

Fizikában a szilárd testeket - azok atomos szerkezetét elhanyagolva - határozott alakkal rendelkező, folytonos anyagnak tekintjük. A szilárd testek külső erőhatásra alakváltozást (deformációt) szenvednek, amelyek ellenében belső erők, feszültségek ébrednek. Legegyszerúbb esetben kis alakváltozást feltételezve, a két fizikai mennyiség (feszültség és deformáció) között egyenes arányosság áll fenn, az arányossági tényező az anyagra jellemző állandó. Ezt a kapcsolatot lineáris közelítésben a Hooke-törvény ${ }^{13}$ fejezi ki. A deformáció típusa szerint létezik nyújtás, összenyomás, nyírás, hajlítás, csavarás. A rugalmas alakváltozás határán túl maradó alakváltozás lép fel, amikor a külső erőhatás megszűnését követően a deformáció megmarad. A külső erőt tovább növelve az anyag elszakad, eltörik. A csontok, belső szervek, használati tárgyak, eszközök nyújtással, összenyomással, hajlítással, csavarással szembeni ellenálló képességének vizsgálata jelentős területe a törvényszéki fizikának.

\section{A rosszul elsült önakasztás fizikája}

A magyarországi öngyilkosságok kivitelezési módjai közül egyértelmúen az önakasztás dominál (1970 és 2010 között 57,4\%). ${ }^{14}$ A 19. és 20. század fordulóján az USA-ban az elítélt bűnözőkre kiszabott halálbüntetés végrehajtásának népszerú formája szintén a kötél általi halál volt. A 19. század végéig az ítéletek végrehajtói a 2-5. nyakcsigolyák eltöréséhez $5600 \mathrm{~N}$ nagyságú erőhatással számoltak, így munkájuk során 1-3 m hosszúságú kötelet alkalmaztak. Ennek az egyik áldozata, a hírhedt bandita, Thomas „Black Jack” Ketchum volt, akit 1901-ben Új Mexikóban kötél által, nyilvánosan kivégeztek. A kötél azonban túl hosszúnak bizonyult, és meglehetősen véres jelenet zajlott le. Ketchum feje a törzséről leszakadva végiggurult a földön. Amennyiben a kötél túl rövid, a nyaki erek és a légcső elzáródásának következtében a halál lassan (10-20 perc) áll be, ellenkező esetben pedig a kivégzés lefejezéssel (dekapitációval) jár együtt. Az elhibázott akasztások gyakori esetnek számítottak világszerte, ami végül a villamosszék feltalálásához vezetett. ${ }^{15}$ Néhány magyarországi önakasztás hasonló módon ért véget, ami a holttestet megtaláló személy számára sokkoló látvány lehetett. Egyes esetekben a nyomozó hatóság a fizikus szakértőkhöz fordult segítségért, magyarázatért.

Az akasztás fizikáját könnyen megérthetjük a munkatétel alapján. A test által megtett út és a test lefékezéséhez szükséges úthossz (a kötél megnyúlása néhány centiméternek vehető) hányadosa nagymértékben befolyásolja - a nyakra ható erők nagyságán keresztül - az akasztás végkimenetelét. A halálra ítélt testtömegének és testmagasságának függvényében optimálisan megválasztott kötélhossz esetén (1,2-1,8 m) a nyakcsigolyák törésével és a gerincvelő szakadásával járó sérülések azonnali halálhoz vezettek.

\footnotetext{
A rugalmas testekben a kitérítéssel arányos, azzal ellentétes irányú erő ébred.

Zonda-Paksi-Veres (2013)

https://en.wikipedia.org/wiki/Hanging (2019. 10. 01.)
} 
A számítások alapján - egyéb körülményeket is figyelembe véve - 4400 N nagyságú erőhatás is elegendő a kívánt hatás eléréséhez.

$\mathrm{Az}$ összehasonlíthatóság kedvéért szemléletes képet kapunk a fellépő erőhatás nagyságáról, ha az eredő erőt a repülésben és az űrhajózásban megszokott g gyorsulás egységben fejezzük ki. A g nehézségi gyorsulás értéke Magyarországon tengerszinten $9,81 \frac{\mathrm{m}}{\mathrm{s}^{2}}$. Amennyiben például egy ember $3 \mathrm{~g}$ gyorsulással mozog, akkor a rá ható eredő erố éppen a nyugalmi állapotában mért súlyának a háromszorosa. ${ }^{16}$ Felhasználva a korábbi adatokat, az akasztáskor fellépő gyorsulás ebben az új egységben számítva mintegy 440 g. A 10 g feletti gyorsulásokat még a kiképzett pilóták szervezete is csak rövid ideig képes tolerálni.

\section{Gyermekbántalmazás}

\section{Newton II. törvénye}

A gyerekbántalmazás alapvetően négy kategóriába sorolható (testi, lelki, szexuális bántalmazás és elhanyagolás). Egy kutatás alapján az esetek döntő többségében (95\%) az elkövetők a bántalmazott gyermek szülei voltak. Elsődlegesen lelki, illetve fizikai sérülést okoztak. Ezeknél a bűncselekményeknél különösen magas lehet a látencia, hiszen egy néhány hónapos csecsemő még nem képes érdekeinek érvényesítésére vagy segítségkérésre. Ilyen korú gyermekek sérelmére elkövetett cselekmények közül a testi bántalmazás deríthető fel nagyobb eredménnyel, amiben a fizikus szakértőkre is felelősségteljes szerep hárul. ${ }^{17}$

A bántalmazás során elszenvedett sérülések keletkezésének fizikája nagymértékű hasonlóságot mutat a közlekedési balesetek mechanizmusával. Bármilyen ütközés két test rövid ideig tartó mechanikai kölcsönhatásaként értelmezhető. Ennek a pillanatszerű eseménynek a mélyebb tárgyalása segítséget nyújthat azoknak a fizikai folyamatoknak a megértéséhez, amelyet ilyen ügyek vizsgálatához a fizikus szakértők alkalmaznak. A balesetek és a bántalmazások súlyosságát első közelítésben az emberi testre ható erők nagysága szabja meg. Egy ütközés közben fellépő eredő F erő nagysága - Newton második törvénye értelmében - adott tömegű test esetén csak a gyorsulástól függ. Ez az axióma Newton eredeti megfogalmazásában úgy magyarázható, hogy ha egy testet hirtelen mozgásba akarunk hozni vagy meg akarunk állítani, akkor egy másiknak nagyon nagy erővel kell hatnia rá. Ebből következik, hogy az erő nagysága függ a sebességváltozás időtartamától is, tehát annál nagyobb az erő, minél rövidebb idő alatt hozzuk mozgásba vagy fékezzük le a testet. Egy test mozgásállapotának, vagyis impulzusának megváltozása az úgynevezett erőlökéssel egyenlő. Az autóbalesetek súlyos következményeinek elkerülése érdekében a mérnökök a tervezéskor ezeket az ismereteket figyelembe veszik, és az ütközéskor ható eredő erő nagyságát

\footnotetext{
A g egységekben mért gyorsulás a mozgó test súlyában, mint egységben adja meg a testre ható eredő erőt. 17 Balogh (2018)
} 
csökkenteni igyekeznek. Olyan műszaki megoldásokat alkalmaznak (energiaelnyelő zóna), amellyel a deformációs úthosszt és az ütközési időt megnövelik, így az utasokra ható erő kisebb lesz. ${ }^{18}$

A nehézségi erő hatására adott földrajzi helyen és tengerszint felett állandó, g gyorsulással a testek függőlegesen, szabadon esnek. Adott magasságból különböző felületekre történő szabadesés ütközésként fogható fel. ${ }^{19}$ A lejátszódó folyamatokat kísérletek és numerikus módszerekkel végzett számítógépes szimulációk segítségével lehet tanulmányozni. A szakirodalomban megtalálható adatok szerint a koponyacsont és a kemény talaj között bekövetkező ütközéskor a fellépő kölcsönhatás pillanatszerú, tipikusan 0,05 és 0,1 másodperc közötti időtartam. Amennyiben egy csecsemő a testméreteihez képest nagy, például 1,8 m magasságból leesik, 21,6km/h sebességgel ér földet. Az autóbalesetek fizikai alapjainak magyarázatához hasonló gondolatmenettel egy gyermekre földre eséskor ható, eredő erő nagysága is megbecsülhető, elérheti az 1000 Newtont is. ${ }^{20}$ Minden ilyen és ehhez hasonló nagyságú eredő erő hatásaként bekövetkezhet kétoldali, úgynevezett vonalas koponyatörés. ${ }^{21}$

Előfordulhat, hogy a szülőknek más személy felügyeletére kell bízniuk gyermeküket. Amennyiben a gyermekre vigyázó felnőtt nem kellő gondossággal jár el, akaratán kívül, magatartásával előidézhet olyan fatális balesetet, amelynek büntetőjogi következménye lesz. A hordozható, többfunkciós babaülés számtalan esetben okozott már tragédiát. Említsünk példaként egy hétköznapi történetet, ahol egy néhány hónapos csecsemőt az évszaknak megfelelően, rétegesen, meleg ruházatban egy ilyen babaülésbe fektetnek, és megkérik a gyermek felügyeletével megbízott személyt, hogy altassa el. Mivel a gyermek sírni kezd, az alkalmi bébiszitter a babahordozó ütemes ringatásával nyugtatni próbálja. Ringatás közben a karja hamar kifárad, ezért maga előtt a levegőben kb. 1 méter magasságban egyik kezéből átlendíti a másikba, azonban átvétel közben a babahordozó mủanyag fogantyúja kicsúszik a tenyeréből, és a földre ejti a csecsemővel együtt. A gyermek ezután felsír, vigasztalhatatlan, ráadásul duzzanat jelenik meg a fején. A kórházban az elvégzett vizsgálatok alapján a gyerekorvos megállapítja, hogy a gyermek kétoldali, vonalas koponyatörést szenvedett. Az orvos a bébiszitter által elmondott baleseti mechanizmus és a sérülés súlyossága között nem talált okokozati összefüggést, ezért értesíti a hatóságot, és eljárás indul az igazság kiderítése érdekében. Egy ilyen esetben a fizikus szakértők a vallomásokra és a szakirodalomra támaszkodhatnak, ${ }^{22}$ annak megfelelően terveznek modellkísérletet.

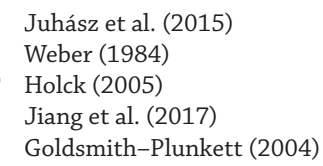


A kísérleti összeállításban a csecsemő műanyag játékbabával helyettesíthető (5. ábra). A fejét ért erőhatások becslésének céljából pedig arra okostelefont erősítenek, aminek gyorsulásmérő szenzora a tér három irányának megfelelően képes rögzíteni - egy speciális applikáció (PhysApp) ${ }^{23}$ segítségével - a gyorsulásértékeket (6. ábra).
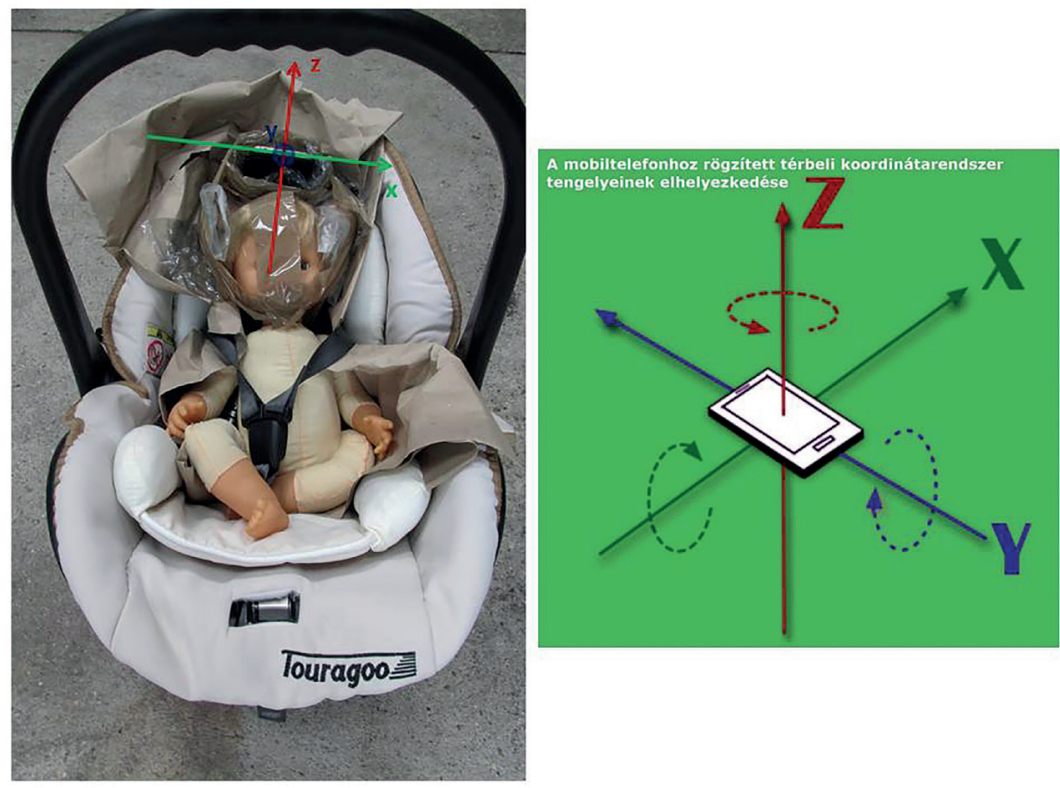

5. ábra: A modellkísérletek során alkalmazott eszközök. Forrás: a szerző szerkesztése

A mérések szerint az ütközéskor kb. $300 \mathrm{~N}$ nagyságú erő hatott a baba fejére. A kísérletek során a játékbabára a babahordozón keresztül, nagy felületen ható erők egy nagyságrenddel kisebbnek adódtak a szakirodalmi adathoz (1000 N) képest. A keletkező sérülések szempontjából a kibélelt babahordozó, a gyermek hűvösebb időjárásnak megfelelő ruházata kedvezően befolyásolhatta az esés és a becsapódás következményeit. Az eredmények tehát nem igazolták a vallomást.

${ }_{23}$ https://users.itk.ppke.hu/itk_dekani/files/Fizika2/pdfs/PhysApp-konferencia_demo.pdf (2019. 10. 01.) 


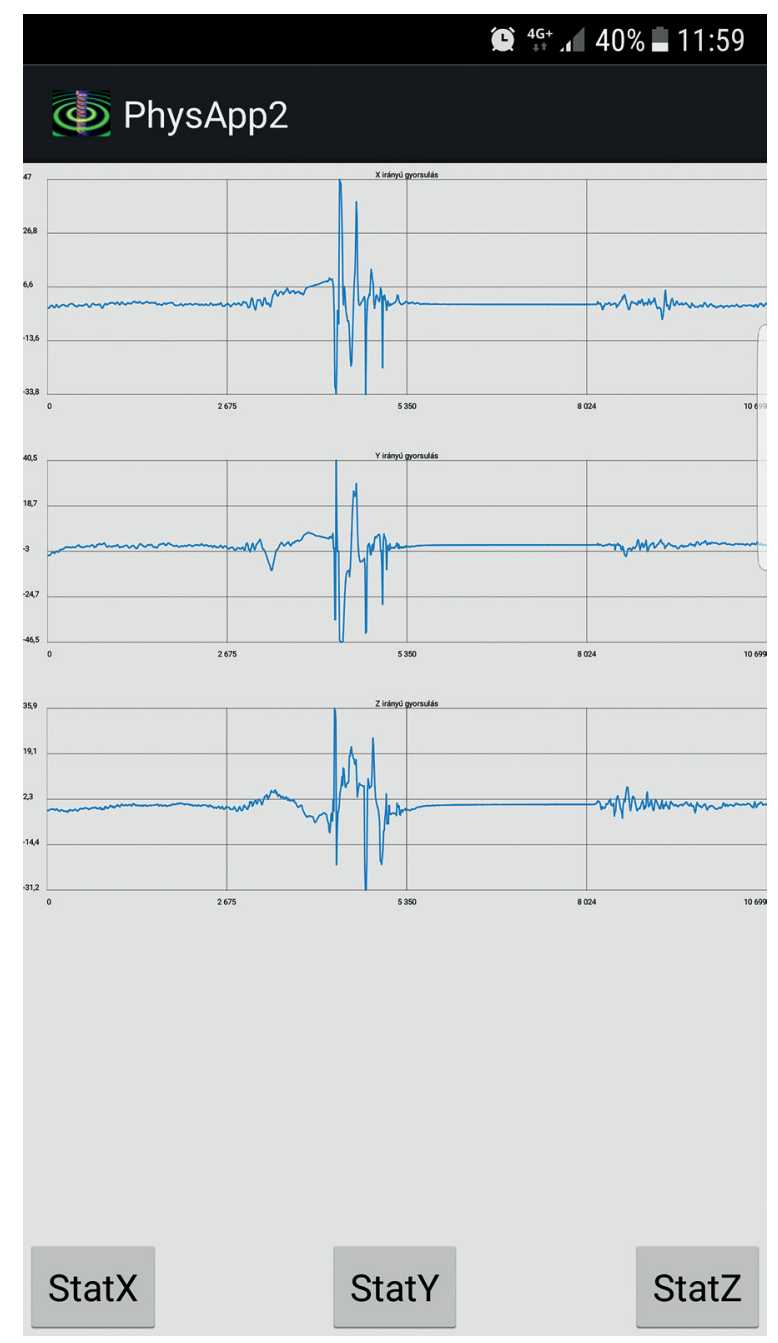

6. ábra: A mobilapplikáció által regisztrált gyorsulásértékek a tér három irányában.

Forrás: a szerző szerkesztése

Egy 2019-ben megjelent tanulmány szerint azonban fordított eset is előfordulhat. A publikációban két balesetet is részletesen megvizsgáltak. A gyakorló orvos számára elsőre egyértelmúen bántalmazásnak látszó sérülésekről - pontos 3D-s CT-felvételek, valamint numerikus módszerekkel elvégzett számítógépes szimulációk segítségével - kiderült, hogy a gyermek felügyeletével megbízott felnőtt által elmondott módon, baleset és nem szándékos bántalmazás következtében szenvedett a csecsemó súlyos 
fejsérülést. ${ }^{24} \mathrm{~A}$ példaként hozott eset tanulsága, hogy orvosként mindig merüljön fel a búncselekmény gyanúja, azonban az ártatlanság vélelme mindenkit megillet, amíg annak ellenkezője be nem bizonyosodik a modern természettudományos és műszaki ismereteknek köszönhetően.

\section{A testek eldőlésének fizikája}

Esetenként előfordul, hogy egy külső erőhatást, annak emberi testre gyakorolt hatását kell modellezni. Ilyen kísérleteknél elsődleges szempont a kísérletet végzők testi épségének védelme. Ennek érdekében az emberi testet sertéshússal, sertéscsontokkal lehet helyettesíteni. A szakértői munkában viszonylag gyakori esetnek számítanak a nehéz, több száz kilogramm tömegű testek felborulása, lebillenése, valamint végtagokra történő zuhanása. Ilyen esetekben a fizikus szakértők feladata a billenési szög és a billenő erő meghatározása. Ehhez olyan kísérleteket terveznek, amivel egy nehéz test ledőlésének mechanizmusa pontosan megfigyelhető, kielemezhető, illetve megállapítható, hogy az emberi testet összenyomva milyen sérüléseket képes okozni.

A fizika fontos módszerei közé tartozik, hogy kísérletek eredményeit számításokkal alá lehet támasztani, illetve a számítások helyességét kísérlettel is lehet ellenőrizni. Ennek érdekében az elvégzett kísérleteket videófelvételeken célszerű rögzíteni. Így már a kísérleti eredmények alapján lehet következtetni arra, hogy bizonyos feltételek (például kis alátámasztási felület) esetén akár egy kisgyermek is képes lehet önerőből több száz kilogramm tömegű testet lerántani.

A számítások alapját képezi, hogy egy merevtest-állás szilárdságát geometriai értelemben a billenési szöggel lehet jellemezni (7. ábra). Ez azt jelenti, hogy a testet legalább ilyen szögben megdöntve (a nehézségi erő hatásvonala ekkor az alátámasztási felületen kívülre esik) labilis egyensúlyi helyzetbe kerül, és lebillen a nehézségi erő forgató hatása miatt.

Dinamikai szempontból annál könnyebb felborítani egy testet

- minél kisebb a test tömege (súlya);

- minél kisebb az alátámasztási felület;

- minél magasabban van a billenő erő támadáspontja az alátámasztási felülettől.

$\operatorname{Li}(2019)$ 


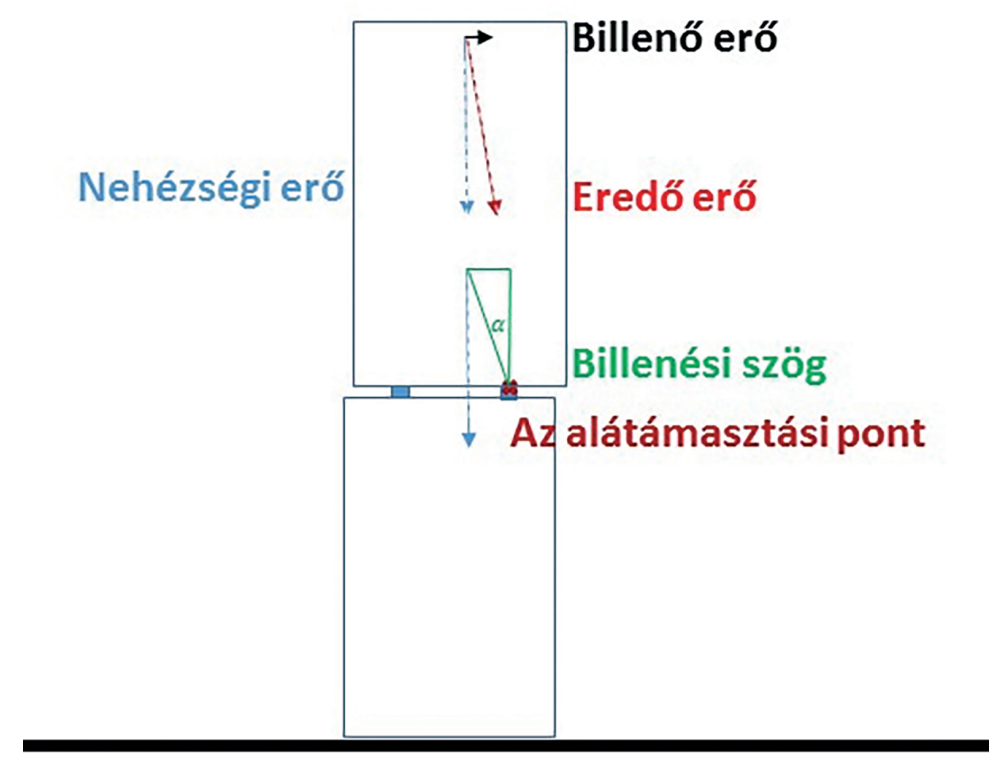

7. ábra: A lebillenés fizikai feltétele. Forrás: a szerzô szerkesztése

Szakértői feladat annak a kérdésnek a tisztázása, hogy a nehéz tárgy kimozdításához, felborításához szükséges izomerőt ki tud-e fejteni egy gyermek, egy nő vagy egy férfi. Ilyen esetekben a szakértők törekednek arra, hogy lehetőleg az eredeti bűnjeltárgy felhasználásával végezzék a modellkísérleteket. Ezek eredményeiből gyakran lehetséges következtetni arra, hogy az elszenvedett sérülések valóban megfelelnek-e a baleseti mechanizmusnak. Az igazságügyi orvos szakértő segítséget nyújthat abban is, hogy a sérülések keletkezéséről nyilatkozik. Nem ritka, hogy egy sebzés vagy törés nem az elmondott esemény vagy cselekmény következménye, valamiért kakukktojásnak számít. Ha egy személyre borul egy nehéz test, akkor azt várnánk, hogy többszörös csonttöréseket szenved, a hasüregi, belső szervek sérülnek, valamint az érintett testrészeken összenyomatásnak megfelelő, nyílt sérülések nyomait fogjuk látni. Ilyen ügyekben egyesített igazságügyi fizikus és orvos szakértői vélemény keretében célszerű kialakítani a szakmai álláspontokat, így meggyőző erejük nagyobb lehet egy büntető eljárás során. Annak megítélése, hogy életszerü-e, zárt logikai láncot alkot-e az előadott eseménysorozat, fontos része a szakértói vizsgálatnak is. Amennyiben ezeknek a feltételeknek nem tesz eleget a felvázolt cselekmény, olyan körülményeket keresnek a szakértők, amivel minden mozzanat rekonstruálható. Alkalmanként új megvilágításba helyezheti az addigi elképzeléseket egy lábbeli nyoma vagy egy jellegzetes alakú tárgytól származó horzsolás is. Természetesen a szakértői törvény is szabályozza 
mindezt, a jogalkotó részletesen megfogalmazta a szakértőkkel szemben támasztott követelményeket, kötelezettségeket. ${ }^{25}$

Amennyiben az üggyel kapcsolatban jelentős körülmény a szakértő tudomására jut, az illetékes hatóságot tájékoztatni köteles. Esetenként így fény derülhet az elkövető kilétére, az elkövetés módszerére, esetleg indirekt módon olyan bizonyítékokat tárhat fel a szakértő, amivel megerősítheti, cáfolhatja az eljárásban részt vevők által elmondottakat.

\section{Munkahelyi balesetek}

\section{Az emberi viselkedés fizikai aspektusa}

Hol van a fizikus szakértők kompetenciájának a határa? Bármelyik gyár üzemében történhet emberi mulasztásból fakadóan fatális munkahelyi baleset. Egy halállal végződő szerencsétlenség felelősének megállapítása hatósági eljárást vont maga után. Ha egy üzemi baleset a biztonsági kamerák látókörén kívülre esik, akkor csak a bűnügyi technikusok által rögzített fényképfelvételekből, egy lehetséges szemtanúvallomásából, valamint a fizika törvényeiből, mozgásegyenleteiből lehet kiindulni. A szakértői munka során az eredeti bünjellel (például a mérete, a tömege miatt) még a helyszínen sem mindig van lehetőség modellkísérletet végezni, ezért a szakértők ilyenkor számítógép segítségével próbálják rekonstruálni a történteket.

Egy szabálytalan alakú test mozgásának vizsgálatához - a célnak megfelelően - egyszerűsítésekkel lehet és kell élni, így egy bonyolult geometriájú test sokszor téglatest alakú modellel helyettesíthető a mozgáselemző szoftverben ${ }^{26}$ (8. ábra).

2016. évi XXIX. törvény az igazságügyi szakértőkről 39. § (3) és a 45. § (4) b) pontja alapján.

www.geogebra.org/?lang=hu (2019. 10. 01.) 


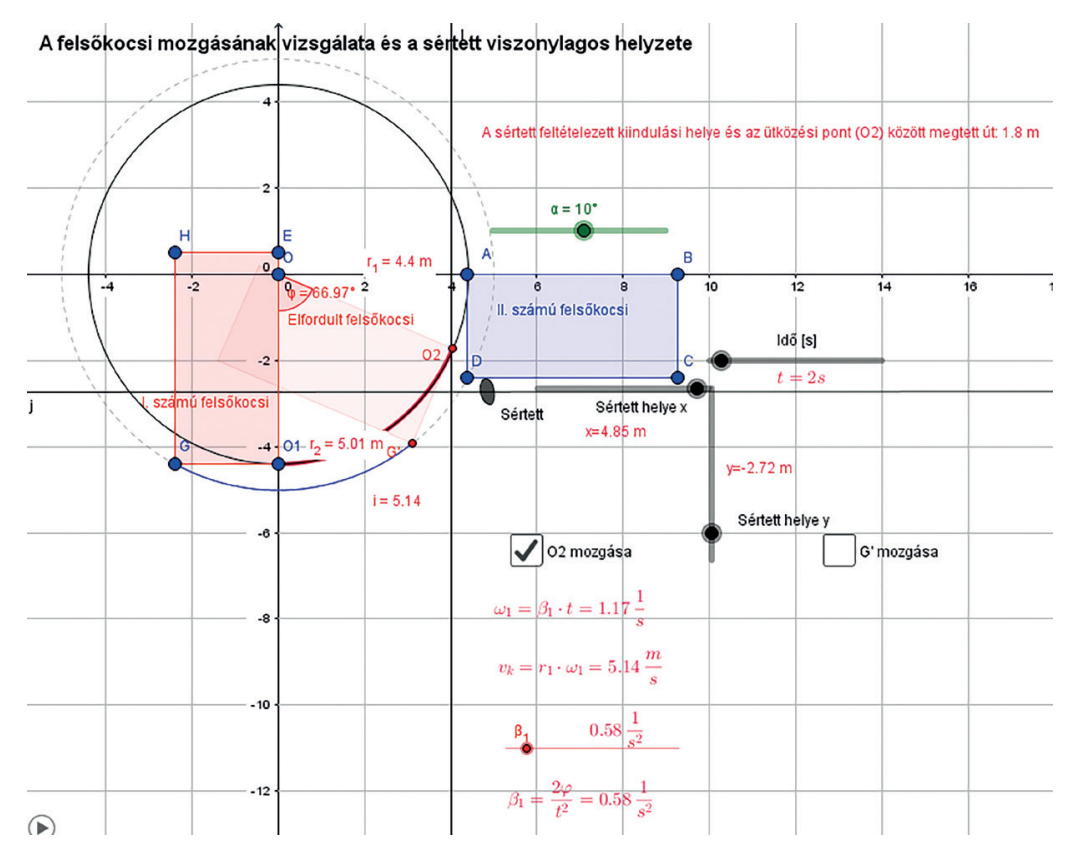

8. ábra: Egy téglatest mozgásának felülnézeti vetülete. Forrás: a szerző szerkesztése

Egy-egy esetet tovább nehezíthet, hogy az igazságszolgáltatásnak az objektív döntéshozatalhoz a sértett baleset előtti helyzetét és a baleset ideje alatt tanúsított viselkedését, valamint a mozgását is ismernie szükséges. A viselkedés külső és belső környezetből érkező ingerekre adott összetett válasz. Ez fizikai értelemben nehezen magyarázható fogalom. Az emberi viselkedés az idegrendszer alapvető múködési elvének, az inger-válasz elvnek a segítségével írható le. Jelen esetben egy hirtelen fellépő, erős, külső ingerre (például ledőlő, nehéz test) az idegrendszer a mozdulatlansági reflexszel válaszolhat, amit fizikailag nem jól definiálható, nem objektív tényezők is befolyásolnak. ${ }^{27}$ A mozgástan ezen aspektusával, a mozgásszabályozással, a reflexekkel kapcsolatos kérdésekkel inkább az élettudományok (például orvostudomány, pszichológia) foglalkoznak, így a fizikus szakértő az átlagos reakcióidőből (0,6 s), az átlagos lépéshossz mértékéből $(53 \mathrm{~cm})$ és a gyaloglás átlagos sebességéből $(1,45 \mathrm{~m} / \mathrm{s} \approx 5 \mathrm{~km} / \mathrm{h})$ tud következtetni egy ember mozgására. ${ }^{28}$ A személy mozgás előtti szándékáról, viselkedéséről objektív módszerekkel azonban nem lehet nyilatkozni.

\footnotetext{
27 Ángyán (2005) 92., 113., 121-124.

28 Damjanovich-Fidy-Szöllősi (2006) 370.
} 


\section{Összefoglalás}

A fizikának mint alaptudománynak egyik alkalmazott területe a törvényszéki vagy forenzikus fizika, amely a tudományos ismeretek mellett kriminalisztikai szemléletmódot is megkíván a szakértőktől. Elsődleges feladatuk a fizikailag legvalószínűbb magyarázatot adni egy esemény- vagy cselekménysorozatra. A különféle esetek ismertetése során célom volt ennek a gyakorlati oldalát bemutatni. Ezek összetettsége az igazságügyi fizikus szakértőktől sokféle módszer alkalmazását követeli meg. Az eredmények értékelésekor a magyarázatot valószínűségi kategóriákba sorolva adják meg. A rájuk bízott ügyet mindig kellő szkepticizmussal, teljes pártatlansággal, a tudomány mai állásának megfelelő, legújabb ismereteket felhasználva kell megoldaniuk. Az igazság kiderítése szempontjából és az adott kérdésnek több tudományterülettel való szoros viszonya miatt elengedhetetlen a szakterületek közötti együttműködés.

\section{IRODALOMJEGYZÉK}

Ángyán Lajos (2005): Az emberi test mozgástana. Pécs, Motio Kiadó.

Balogh Anna (2018): Kiskorú veszélyeztetésének bűntette a bírósági határozatok kritikai tükrében. Ügyészek Lapja, 25. évf. 3. sz. 5-28.

Budó Ágoston (1986): Kísérleti fizika. I. kötet. Budapest, Nemzeti Tankönyvkiadó Rt.

Damjanovich Sándor - Fidy Judit - Szöllősi János (2006): Orvosi biofizika. Budapest, Medicina Könyvkiadó Zrt.

Goldsmith, Werner - Plunkett, John (2004): A biomechanical analysis of the causes of traumatic brain injury in infants and children. The American Journal of Forensic Medicine and Pathology, Vol. 25, No 2. 89-100. DOI: https://doi.org/10.1097/01.paf.0000127407.28071.63

Holck, Per (2005): What can a baby's skull withstand? Testing the skull's resistance on an anatomical preparation. Forensic Science International, Vol. 151, No. 2-3. 187-191. DOI: https://doi.org/10.1016/j.forsciint.2004.12.038

Jiang, Binhui - Zhu, Feng - Cao, Libo - Presley, Barbara - Shen, Ming - Yang, King H. (2017): Computational Study of Fracture Characteristics in Infant Skulls Using a Simplified Finite Element Model. Journal of Forensic Sciences, Vol. 62, No. 1. 39-49. DOI: https://doi.org/10.1111/1556-4029.13241

Juhász András - Tasnádi Péter - Jenei Péter - Illy Judit - Wiener Csilla - Főzy István (2015): A fizika tanitása a középiskolában I. Egyetemi jegyzet. ELTE. Forrás: http://csodafizika.hu/fiztan/letolt/fizika_tanitasa_1.pdf (2019.10.01.)

Li, Xiaogai (2019): Infant Skull fractures: Accident or abuse? Evidences from biomechanical analysis using finite element headmodel. Forensic Science International, Vol. 294, 173-182. DOI: https://doi. org/10.1016/j.forsciint.2018.11.008

Tóth Péter (2013): Szakmódszertan - Gépészet-mechatronika szakirány. Budapest, Óbudai Egyetem. Forrás: www.tankonyvtar.hu/hu/tartalom/tamop412b2/2013-0002_szakmodszertan_gepeszet_mechatronika/tananyag/00-borito-150604a-halvanysarga-03-Toth.Peter.html (2019. 10. 01.)

Weber, Werner (1984): Experimentelle Untersuchungen zu Schädelbruchverletzungen des Säuglings. Zeitschrift für Rechtsmedizin, Vol. 92, No. 2. 87-94. DOI: https://doi.org/10.1007/BF02116216

\section{Internetes források}

https://physlets.org/tracker/ (2019. 10. 01.)

https://en.wikipedia.org/wiki/Hanging (2019. 10. 01.) 
https://users.itk.ppke.hu/itk_dekani/files/Fizika2/pdfs/PhysApp-konferencia_demo.pdf (2019. 10. 01.) www.geogebra.org/?lang=hu (2019. 10. 01.)

Zonda Tamás - Paksi Borbála - Veres Előd (2013): Az öngyilkosságok alakulása Magyarországon (19702010). Forrás: www.ksh.hu/docs/hun/xftp/idoszaki/pdf/muhelytanulmanyok2.pdf (2019. 10. 01.)

\section{Jogforrások}

2016. évi XXIX. törvény az igazságügyi szakértőkről

2017. évi XC. törvény a büntetőeljárásról

\section{ABSTRACT}

\section{Brutality of Physics from a Different Aspect - Physicists on the Trail of Truth}

FÜLÖP Péter

The qualitative and quantitative description of physical processes in various crimes and accidents is the competence of forensic physicist experts. The most frequent cases can be categorised quite easily in the aspects of physics. Through the physics of projectile motion and deformation, the reader can get a general idea of the methods used in practice. In my study, I also explain a few concepts and quantities briefly as they make it easier to understand these principles and phenomena.

Keywords: forensic physics, death due to a criminal act, suicide, accident, child abuse, Newtonian laws, force, momentum, kinetic energy, projectile motion, deformation 